\title{
The determination of the success factors of the new entrepreneurs of growth program
}

\author{
Warcito, Hamidah and Corry Yohanna \\ Jakarta State University, UNJ Jakarta Indonesia. \\ Global Journal of Engineering and Technology Advances, 2021, 08(01), 061-071 \\ Publication history: Received on 06 June 2021; revised on 13 July 2021; accepted on 15 July 2021
}

Article DOI: https://doi.org/10.30574/gjeta.2021.8.1.0101

\begin{abstract}
This study aims to describe the implementation of the New Entrepreneurial Program (WUB) in Bogor Regency, West Java, and determine the level of success. This study uses a descriptive evaluative approach, micro and small business owners in Bogor Regency. Respondents were selected deliberately, namely 164 participants of the 2017-2018 New Entrepreneurship program in Bogor Regency. The results showed that the New Entrepreneurial Growth Program in Bogor Regency with the CIPP Model (Context, Input, Process, and Product) can be declared successful with the percentage of the total success rate obtained 79.9\%. However, it is necessary to improve the quality of the implementation so that it can be achieved optimally. As part of the effort to accelerate the Micro, Small, and Medium Enterprises (MSMEs) program to graduate in Bogor Regency, West Java, the pattern of growing the number and quality of MSMEs can be carried out by printing MSMEs Families.
\end{abstract}

Keywords: Success Factors; New Entrepreneurs (WUB); Micro, Small and Medium Enterprises (MSMEs)

\section{Introduction}

New entrepreneurial growth activities in Bogor Regency began in 2017 based on the Decree of the Head of the Bogor Regency Small and Medium Enterprises Cooperative Office Number 518.3 / 155.A / KPTS / PUM / VIII / 2017 dated 1 August 2017 concerning the Implementation Team for New Entrepreneurial Planting Activities in Bogor Regency. The development of new entrepreneurs in Bogor Regency aims to improve the knowledge and skills of business actors regarding management and entrepreneurship and to encourage new entrepreneurs or business actors to manage their businesses with knowledge gained through training. According to Dhamayantie and Fauzan (2017), they state that in increasing the competitiveness of Small and Medium Enterprises (SME), local government support, especially in terms of facilitation, is urgently needed by SME players.

The new entrepreneurship program in Bogor Regency was implemented from 3 October 2017 to December 2018. The number of participants who have been involved in 450 MSMEs from 40 sub-districts in Bogor Regency. The 2019 activity was attended by 40 MSME players from 8 sub-districts with speakers from UPTD P3W West Java, PT. ABCo Sugesti Motivatindo, Koko Gibran entrepreneur, and Kedai Mpek-Mpek Bu Ota entrepreneur (Nawawi, 2012).

The new entrepreneurial growth program includes training carried out with a classroom learning model that presents 13 material titles, including 1) Group Dynamics, 2) Entrepreneurial Motivation, 3) Measuring the Quality of Personal Entrepreneurship (KKP), 4) Entrepreneurship Mindset, 5) Sharing Business: Business Financing and Government Programs, 6) Building Entrepreneurial Attitudes, 7) Small Business Management and Marketing, 8) Exploring and Developing Business Ideas, 9) Compiling Business Plans, 10) Sharing Business Development and Branding, 11) Simple Bookkeeping Practices for MSMEs, 12) Marketing Strategy and 13) Development of New Entrepreneurial Business

\footnotetext{
${ }^{*}$ Corresponding author: Warcito

Jakarta State University, UNJ Jakarta Indonesia. 
Network. The learning methods in training are in the form of lectures, discussions, counting practice, presentations, and internships (Mulyatiningsih and Nuryanto, 2014).

The follow-up to training activities is an apprenticeship that aims to accelerate the change in behavior of MSMEs actors as prospective new entrepreneurs. The results of the evaluation of the implementation of the training show that the participants are quite disciplined, active during the training, cooperative, and always do their assignments. Participants feel helped in running their business because participants have new insights, new knowledge, and new skills, especially in business management. From these activities, it is interesting to research, how is the description of the implementation of the New Entrepreneurial Program in Bogor Regency? and What is the level of success of the New Entrepreneurial Program in Bogor Regency?

\section{Material and methods}

\subsection{New Entrepreneurial Program (WUB)}

The WUB program is a program established by Ahmad Heryawan as the Governor of West Java for the 2014-2018 period in West Java Governor Regulation Number 79 of 2015. This program is held to respond to the need for reliable human resources in increasing business productivity and competitiveness in West Java (Nugroho et al, 2020). This program emphasizes the development of entrepreneurship intending to give birth to new entrepreneurs who are innovative, creative and independent, as well as competitive. The New Entrepreneurial Program consists of three activities, namely: 1) Entrepreneurship Training for New Entrepreneurs, 2) Apprenticeship for Training Participants, and 3) Entrepreneurship Mentoring / Mentoring (Nugroho et al, 2019).

The target for achieving the New Entrepreneurial Program is the printing of one hundred thousand New Entrepreneurs. To achieve this target, the New Entrepreneurial Program uses the "Jabar Masagi" strategy which involves various parties, namely the Government, Academics, Communities, and the Business World. Besides, the growth of new businesses as a foundation for MSMEs to go up to grade with the indicators of Law Number 20 of 2008, concerning Micro, Small, and Medium Enterprises (MSMEs). Reeg (2013) defines upgrading or upgrading as the growth of SMEs through a process of innovation.

\subsection{Entrepreneurship Training for New Entrepreneurs}

Not everyone can take this training. There are three criteria for participants who can participate in this training, namely: 1) Business ideas (0 years), 2) Startups / Beginners (1-2 years), 3) Growth / Development (3-5 years). The training was held for four days with details of three days in class and 1 day of internship at the company. The number of lessons during the training was 44 lesson hours with $30 \%$ theory lessons and $70 \%$ practical training methods in the form of lectures, discussions, simulations, case studies, and internships. The training materials, namely: 1) Group Dynamics, 2) Excellent Service to Consumers, 3) Calculation of Capital Needs, Income and Costs, Reading Financial Statements, 4) Business Feasibility Study Analysis, 5) Marketing Strategy and Technique, 6) Branding Strategy, 7) Business Communication and Negotiation, 8) Online Sales, 9) Business Partnerships, 10) Business Ethics, 11) Sales Simulation, 12) Production Cost Efficiency, 13) Risk Management, and 14) Mental Physical Discipline (MFD). The instructors, instructors or resource persons for this training consist of 1) Officials in the West Java Province Cooperative and MSMEs Office, 2) Successful practitioners or entrepreneurs in the fields of Food and Beverage, Convection and Beauty Salon Services, 3) Widyaiswara Training Center for Cooperative Personnel and West Java Province MSMEs, 4) Higher Education, 5) KADIN / HIPMI West Java, 6) Business Consultant and 7) West Java DEKOPINWIL.

\subsection{The apprenticeship of Training Participants}

This activity is a series of the first activities, namely Entrepreneurship Training for New Entrepreneurs, where apprenticeship activities are held one day after three days of in-class training. Training participants will be included in an apprenticeship at a company that is following the training participant's line of business. Apprenticeship aims to transfer skills directly from business actors regarding the production process, marketing, access to finance, and experience. Besides, so that the training participants understand the problems in the business world and at the same time motivate the New Entrepreneur participants to develop their business (Roosli and Roosman, 2013).

\subsection{Entrepreneurship Assistance}

After the implementation of the training and apprenticeship, the training participants are assisted by assistants who come from the business world, academics, and/or practitioners who have competence in their fields (Singarimbun and Effendi, 1989). In implementing the assistance, the assistants are tasked with: 1) inventorying problems and providing 
solutions for new entrepreneurs in developing their business, 2) providing technical guidance and facilitating access to business support, 3) facilitating access to licensing and financing through financial institutions, and 4) facilitate access to marketing and promotion of New Entrepreneur products. This is in line with the results of research conducted by Warcito et al (2020) that increasing entrepreneurial motivation among families and communities can be done through mentoring, training, and apprenticeship programs.

\subsection{Program Evaluation}

There are various evaluation models which all have the same purpose and objective, namely collecting data and information regarding the object being evaluated. The results of data collection and information are provided to policymakers so that they can properly decide the follow-up of the program being evaluated (Suharjo et al, 2019). Based on Suharjo's (2019) investigation, there are eight evaluation models, namely: 1) Goal-Oriented Evaluation Model, 2) Goal Free Evaluation Model, 3) Formative Summative Evaluation Model, 4) Countenance Evaluation Model, 5) Responsive Evaluation Model, 6) CSE- UCLA Evaluation Model, 7) CIPP Evaluation Model, 8) Discrepancy Model. The selection of the evaluation model used depends on the purpose of the evaluation (Susilo, 2020).

In this study, the evaluation of the New Entrepreneurial Program is more appropriate using the CIPP Model (Context, Input, Process, and Product) which was initiated by Yu, M. C. (2013). The CIPP model uses a systems approach, which is an approach that includes all activity processes. The components contained in the CIPP Model are as follows:

- Context evaluation is carried out by identifying the background for the need to make changes or the emergence of the program (Mulyatingsih, 2011). Context evaluation is the basis of evaluation that aims to provide reasons for setting goals (Warcito et al, 2020). Context evaluation provides a detailed description of the environment, needs, and goals. Context evaluation includes problem analysis which contains the analysis of the strengths and weaknesses of certain objects. It can be said that the context evaluation deals with the analysis of the strengths and weaknesses of certain objects that will be or are currently running. Context evaluation provides information for decision-makers in planning a program. This analysis will assist in planning decisions, determining needs, and formulating program objectives in a more directed and democratic manner.

- Input evaluation is carried out to identify and assess the capabilities of the material, equipment, human, and cost resources to implement the implemented program (Mulyatiningsih, 2011). Input evaluation helps organize decisions, determine existing sources, what alternatives are taken, what are the plans and strategies to achieve goals, what are the working procedures to achieve them. The input evaluation component includes: 1) Human resources, 2) Supporting facilities and equipment, 3) Funds or budgets, 4) Various procedures and necessary rules.

- Process evaluation aims to identify obstacles in program implementation (Mulyatiningsih, 2011). Process evaluation is used to detect or predict procedure design or implementation design during the implementation phase, provide information for program decisions, and as a record or archive of procedures that have occurred. The evaluation process is directed to find out how far the plans that have been implemented in the program have been implemented according to the plan and what components need to be improved.

- Product evaluation aims to measure, interpret and decide the results that have been achieved by the program (Mulyatiningsih, 2011). Product evaluation is an assessment carried out to measure the success in achieving the goals that have been set. The data generated will determine whether the program is continued, modified, or stopped. The product components in this study include the results of activities obtained from the cognitive, affective, psychomotor, behavioral, and performance aspects.

\subsection{The Research Methods}

This research is descriptive evaluative research. Descriptive research is defined as the problem-solving procedure investigated by describing or describing the current state of the subject or research object based on the facts that appear as they are. Data collection in the form of questionnaires, in-depth interviews, and observations (Statistics B.P, 2015). The research was conducted in Bogor Regency, West Java, with the implementation time from October to December 2019. Figure 1 below is an analysis of the research framework The Determination of The Success Factors of The New Entrepreneurs Growth with a context, input, process, and product approach: 


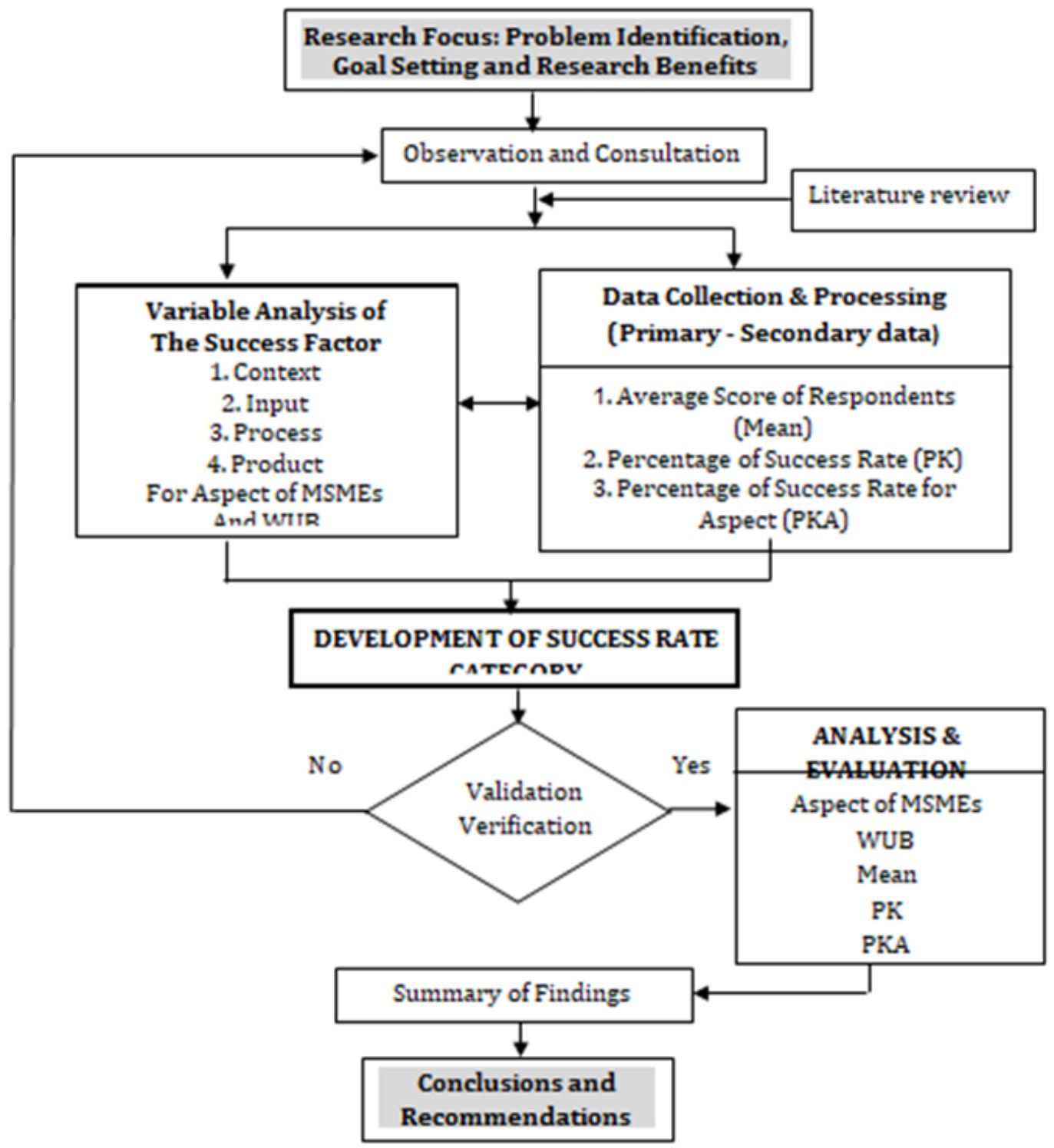

Source: Warcito, 2020

Figure 1 Analytical Framework uses the Context, Input, Process and Product approach

The research was carried out in a period of three months, namely in October - December 2019 in Bogor Regency New Entrepreneur Program participants who were recorded in 2017 and 2018. Participants of the Bogor Regency New Entrepreneurial Program in 2017 totaled 250 people and in 2018 totaled 200 people. The research sample taking in this study follows Suharyo (2017) which states that if the number of research subjects is greater than 100 people, it can take $10-15 \%$ or $20-25 \%$ or more of the total population. The sample of this study amounted to 164 people who were taken as rounding of $36 \%$ of the 450 participants of the New Entrepreneurial Program 2017 and 2018 who were randomly selected proportionally according to the district. In addition to respondents, data sources were obtained from informants consisting of parties relevant to the implementation of the New Entrepreneurial Program, such as the person in charge of the program, program managers, program instructors, and program assistants.

The data analysis technique used in this research is a descriptive evaluative analysis using frequency tables, descriptive statistics, and a matrix to describe the level of achievement or success rate of implementing the New Entrepreneurial Program in Bogor Regency based on the CIPP Model (Context, Input, Process, and Product). The level of achievement or success rate of implementing the New Entrepreneurial Program in each dimension (Context, Input, Process, Product) is obtained using the following formula (Zimmerer et al, 2008): 
$\mathrm{PK}=$ Mean of $(\mathrm{PKA}) \times 100$

The Formulation:

$$
\mathrm{PKA}=\frac{\text { Mean }}{\text { Maximum score range }} \times 100
$$

$\begin{array}{ll}\text { Mean } & =\text { Average Score of Respondents } \\ \text { PK } & \text { = Percentage of Success Rate } \\ \text { PKA } & \text { = Percentage of Success Rate for Aspect }\end{array}$

The success rate of implementing the New Entrepreneurial Program is seen from the percentage of the total success rate of the New Entrepreneurial Program (PKT) which is calculated from the average percentage of success rates in each dimension. The results of the percentage of the total success rate of the New Entrepreneurial Program are categorized so that it can be seen the form of recommendations as presented in Table 1.

Table 1 Categories of Success Rates and Recommended Forms of Evacuation Results

\begin{tabular}{|c|c|l|}
\hline Percentage of Success Rate & Category of Success Rate & Form of Recommendation \\
\hline$<70 \%$ & Less successful & $\begin{array}{l}\text { There need to be improvements in the } \\
\text { planning and implementation strategy of } \\
\text { the WUB program }\end{array}$ \\
\hline $70-85 \%$ & Successful & $\begin{array}{l}\text { It is necessary to improve the quality of } \\
\text { the WUB program }\end{array}$ \\
\hline$>85-100 \%$ & Very successful & Need to develop a WUB program \\
\hline
\end{tabular}

\section{Results and discussion}

The New Entrepreneurial Program is a program that aims to increase human resources as an aspect that supports business productivity. Based on the results of the study, of the 164 respondents consisting of $73.2 \%$ women and $26.8 \%$ men. This happens because most of the micro and small businesses in the Bogor district are side businesses or additional livelihoods (additional livelihoods) managed by women who work as housewives daily. The distribution of respondents based on their domicile is spread across 22 sub-districts in Bogor Regency. The largest number of respondents, namely Cibinong District (11.6\%), Citeureup District (9.75\%), and Ciseeng District (7.93\%). This reflects that MSMEs are quite developed in these sub-districts.

The results of in-depth interviews with program managers, program instructors, and assistants stated that the success of the new entrepreneurial growth program was an important step in achieving MSMEs graduation. Warcito, et al (2020) stated that the MSMEs graduation program begins with the recruitment process for micro and small business consulting clinic participants. Clinical participants are obtained from alumni of new entrepreneurship participants (WUB). The model developed based on the results of this research is the development of new entrepreneurs into basic training for micro and small entrepreneurs. In the second stage, business actors are encouraged to be registered at the micro and small business consulting clinic. In the third stage, business actors participate in skills training according to the problems at hand, for example, problems with financial records, then the business actor will attend financial management training. The last stage, strengthening business groups or institutions. The Office of Cooperatives, Small and Medium Enterprises, Bogor Regency, encourages MSMEs to the group and directs them to form cooperative institutions. This cooperative is a forum for micro and small business actors to develop creativity, innovation, and independence in creating business continuity. The model for increasing the competence of micro and small entrepreneurs in the MSME graduation program in the Bogor district can be explained in Figure 2. 


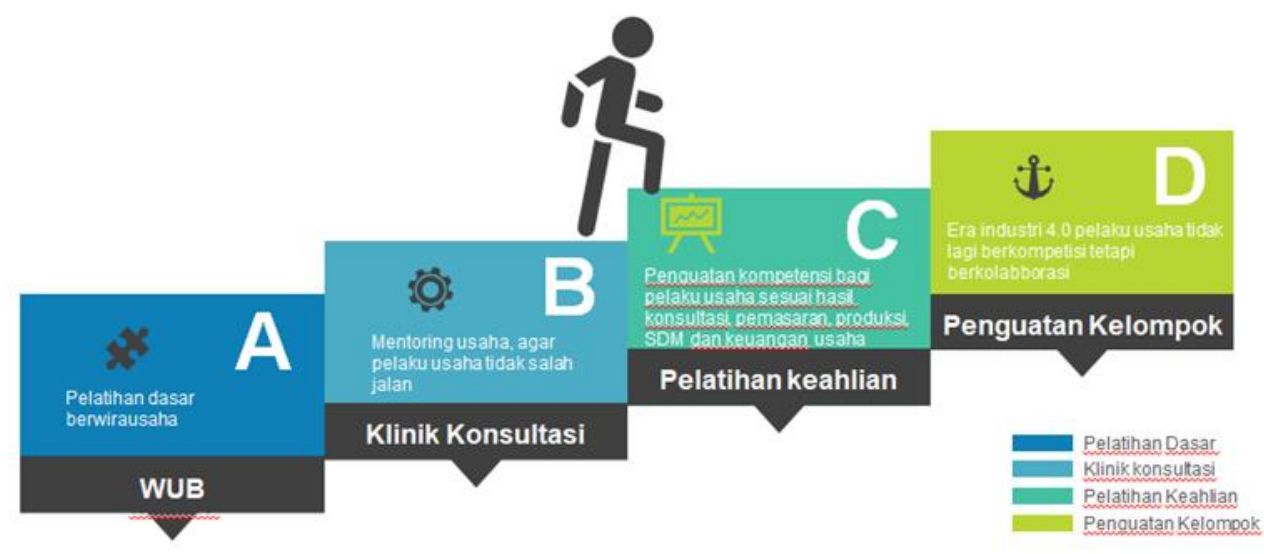

Figure 2 A Model for Increasing the Competence of Micro-Entrepreneurs in the MSMEs

Program for Graduation in Bogor District, Source: Warcito, 2020

In this study, the discussion focused on new entrepreneurial growth programs as basic training for micro and small entrepreneurs in the Bogor district. The success rate of implementing the New Entrepreneurial Program in Bogor Regency is seen from both the percentage of the success rate in each of the evaluated dimensions and the percentage of the success rate of the New Entrepreneurial Program as a whole. The implementation of the New Entrepreneurial Program in the Context dimension is classified as very successful ( $\mathrm{PK}=89.1)$ as seen in Table 2. It can be stated that the implementation of the New Entrepreneurial Program needs to be developed based on aspects of strong program policies, program objectives that match the needs, and positive program benefits. , as well as the right program targets.

Table 2 Descriptive Statistical Calculations on the Context Dimensions of the New Entrepreneurial Program

\begin{tabular}{|l|c|c|l|}
\hline \multicolumn{1}{|c|}{ Aspect } & Mean & PKA (\%) & \multicolumn{1}{c|}{ Summary of Findings } \\
\hline Program policy & 1.87 & 93.5 & $\begin{array}{l}\text { As many as 66.26\% of participants stated that WUB was a } \\
\text { special program for the Bogor Regency Cooperative and } \\
\text { MSMEs Office, while 33.73\% of participants stated that } \\
\text { WUB was a national program and a West Java provincial } \\
\text { program implemented by the Bogor Regency Office of } \\
\text { Cooperatives and MSMEs. }\end{array}$ \\
\hline $\begin{array}{l}\text { Program } \\
\text { objectives }\end{array}$ & 1.69 & 84,5 & $\begin{array}{l}\text { As many as 93.44\% of participants stated that the WUB } \\
\text { program was useful for developing MSMES businesses } \\
\text { because the WUB program provided training on materials } \\
\text { related to business and mentoring. }\end{array}$ \\
\hline Program benefits & 1.73 & 86.5 & $\begin{array}{l}\text { MSMEs practitioners have felt the benefits of the WUB } \\
\text { program. As many as 28.93\% have increased business } \\
\text { networks and 16.93\% have financial records }\end{array}$ \\
\hline $\begin{array}{l}\text { Program } \\
\text { objectives }\end{array}$ & 1.84 & 92.0 & $\begin{array}{l}\text { The WUB program encourages business actors to become } \\
\text { more skilled in managing their business and business } \\
\text { networks. }\end{array}$ \\
\hline $\begin{array}{l}\text { Success Rate (PK) } \\
\text { (\%) }\end{array}$ & 89.1 & $\begin{array}{l}\text { Program policies, program objectives, program benefits, } \\
\text { and program objectives of the New Entrepreneurial } \\
\text { Program have been correctly identified by program } \\
\text { participants. }\end{array}$ \\
\hline
\end{tabular}

Likewise in the Input dimension, it can be seen in Table 3. that the implementation of the New Entrepreneurial Program was classified as very successful ( $\mathrm{PK}=85.3)$. MSMEs actors who participate in the program have met the membership 
requirements as stipulated in the New Entrepreneurial Program Implementation Guidelines. The facilities and infrastructure to support the implementation of the New Entrepreneurial Program are also inadequate conditions.

Table 3 Descriptive Statistical Calculations on the Input Dimensions of the New Entrepreneurial Program

\begin{tabular}{|l|c|c|l|}
\hline \multicolumn{1}{|c|}{ Aspect } & Mean & PKA (\%) & \multicolumn{1}{c|}{ Summary of findings } \\
\hline $\begin{array}{l}\text { Human resource } \\
\text { conditions }\end{array}$ & 1.77 & 88.5 & $\begin{array}{l}\text { The results of the FGDs with program implementers } \\
\text { indicated that the activities had been designed according } \\
\text { to agreed standards and guidelines starting from } \\
\text { identification and outreach in the sub-districts, selection } \\
\text { of participants instructors, training materials, and } \\
\text { implementation methods. Participants per batch of } 40 \\
\text { people with the implementation of activities for 3 days of } \\
\text { training in class and 1 (one) day at production } \\
\text { houses/companies/entrepreneurs according to their line } \\
\text { of business. The implementation committee is from the } \\
\text { Entrepreneurship Improvement Section of } \\
\text { Cooperative and SME Agency for Bogor Regency. }\end{array}$ \\
\hline $\begin{array}{l}\text { Condition of facilities } \\
\text { and infrastructure }\end{array}$ & 1.64 & 82 & $\begin{array}{l}\text { According to respondents, the conditions of the facilities } \\
\text { and infrastructure in the new entrepreneurship program } \\
\text { in Bogor Regency are already good and need to be } \\
\text { improved. The training for new entrepreneurs in the last } \\
\text { 2 years has been optimal, and the process of practical } \\
\text { mentoring has been maximized. Training activities are } \\
\text { carried out in Bogor Regency with full accommodation } \\
\text { (lodging, food and beverage, and transportation costs). }\end{array}$ \\
\hline $\begin{array}{l}\text { Success Rate (PK) } \\
\text { (\%) }\end{array}$ & $\begin{array}{l}\text { The conditions of human resources and conditions of } \\
\text { facilities and infrastructure are appropriate and support } \\
\text { the aims and objectives of implementing the New } \\
\text { Entrepreneurial Program in Bogor Regency. }\end{array}$ \\
\hline
\end{tabular}

Process Dimensions, Table 4 shows that the implementation of the New Entrepreneurial Program is classified as successful ( $\mathrm{PK}=70.7$ ). This means that the process that has been carried out needs to improve the quality of the New Entrepreneurial program in Bogor Regency, especially in the aspects of the suitability of learning media and the suitability of learning methods.

Table 4 Descriptive Statistical Calculations on the Process Dimensions of the New Entrepreneurial Program

\begin{tabular}{|l|l|l|l|}
\hline \multicolumn{1}{|c|}{ Aspect } & Mean & PKA (\%) & \multicolumn{1}{c|}{ Summary of findings } \\
\hline $\begin{array}{l}\text { Instructor } \\
\text { performance }\end{array}$ & 4.33 & 86.6 & $\begin{array}{l}\text { On average, participants assessed that the training instructor's } \\
\text { performance was in a good category, with training instructor } \\
\text { performance indicators, as follows: the ability to deliver material, the } \\
\text { ability to generate motivation, and the ability to answer participant } \\
\text { questions. Several reasons underlie the assessment that the instructor } \\
\text { has performed well, among others: friendly and patient in delivering the } \\
\text { material so that the material becomes easier to understand, not boring, } \\
\text { able to explain correctly so that it is considered capable of changing the } \\
\text { mind-set of MSMES actors. However, due to the limited time to deliver } \\
\text { the material, the participants' understanding has not all improved } \\
\text { optimally. }\end{array}$ \\
\hline $\begin{array}{l}\text { Participant } \\
\text { activities }\end{array}$ & 4.21 & 84.2 & $\begin{array}{l}\text { WUB training participants generally participate actively during the } \\
\text { training. A total of 56.10\% of participants rated their activities as good } \\
\text { and 32.32\% of participants rated their activities as very good. On } \\
\text { average, the participants also considered that the participants' activities } \\
\text { during the training were good. Active participants during the training }\end{array}$ \\
\hline
\end{tabular}




\begin{tabular}{|c|c|c|c|}
\hline & & & $\begin{array}{l}\text { with indicators, namely participants actively asking and answering } \\
\text { questions, enthusiasm during the training, compact, disciplined, } \\
\text { interacting with each other, enthusiastic in every discussion, and } \\
\text { diligent in doing the tasks given by the training instructor. }\end{array}$ \\
\hline $\begin{array}{l}\text { Training } \\
\text { curriculum }\end{array}$ & 4.11 & 82.2 & $\begin{array}{l}\text { In general, the curriculum for the WUB training program is considered } \\
\text { good according to the participants. A total of } 76.83 \% \text { of participants } \\
\text { rated the training curriculum well and } 23.17 \% \text { rated it very well. On } \\
\text { average, participants also considered that the program curriculum } \\
\text { designed to foster new entrepreneurs was in a good category. This good } \\
\text { curriculum indicator is relevant to the performance of the instructor and } \\
\text { the activities of the participants. Good instructor performance and } \\
\text { positive participant activities indicate that the WUB training curriculum } \\
\text { has been assessed as applicative and content-dense. }\end{array}$ \\
\hline $\begin{array}{l}\text { Training } \\
\text { metrics }\end{array}$ & 4.19 & 83.8 & $\begin{array}{l}\text { In general, all the material provided during the WUB training was } \\
\text { considered good ( } 46.34 \%) \text { and very good (36.59\%). On average, the } \\
\text { participants also considered that the feasibility of the material in the } \\
\text { WUB training was good. The material is considered appropriate because } \\
\text { it is easy to learn with the availability of modules or reading material, } \\
\text { easy to understand, the material is following the needs of MSMEs actors, } \\
\text { and the material is innovative. The material provided in the WUB } \\
\text { training is deemed appropriate and adequate in achieving the goals and } \\
\text { objectives of organizing the WUB program. }\end{array}$ \\
\hline $\begin{array}{l}\text { Suitability of } \\
\text { learning } \\
\text { media }\end{array}$ & 3.83 & 76.6 & $\begin{array}{l}\text { The aspect of the suitability of the learning media was assessed evenly, } \\
\text { starting from the highest score, which was good }(60.37 \%) \text { and very good } \\
(13.41 \%) \text {. However, the average participant considered that the } \\
\text { suitability of the learning media was sufficient. Although using fun } \\
\text { learning media, such as audio-visuals, giving quizzes, interesting power } \\
\text { points, the use of these media is deemed insufficient to meet the learning } \\
\text { outcomes and objectives of the training participants. This is because the } \\
\text { learning media used in the training are considered mediocre, the } \\
\text { illustrations are less attractive, are not suitable for the participant's type } \\
\text { of business, are poorly understood, and are less practical according to } \\
\text { the training participants. }\end{array}$ \\
\hline $\begin{array}{l}\text { Suitability of } \\
\text { learning } \\
\text { methods }\end{array}$ & 3.98 & 79.6 & $\begin{array}{l}\text { The learning method was considered good by } 62.20 \% \text { of the participants } \\
\text { and very good by } 18.90 \% \text { of the participants. The average participant } \\
\text { also considered that the appropriateness of the learning method was } \\
\text { good. Methods of lectures, quizzes, exercises, group discussions, games, } \\
\text { accompanied by real case examples. However, there were still } 18.90 \% \\
\text { who gave a negative assessment of the learning methods used. The } \\
\text { learning method used was considered by the participants to be less } \\
\text { suitable for the ability level of the participants. }\end{array}$ \\
\hline \multicolumn{2}{|c|}{$\begin{array}{l}\text { Success Rate (PK) } \\
(\%)\end{array}$} & 70.7 & $\begin{array}{l}\text { The process that has been carried out supports the successful } \\
\text { implementation of the New Entrepreneurial Program in Bogor Regency. }\end{array}$ \\
\hline
\end{tabular}

Product Dimensions, Table 5 shows that the implementation of the New Entrepreneurial Program in Bogor Regency is classified as successful (PKA = 74.5). This means that the products produced need to improve the quality of the New Entrepreneurial program in Bogor Regency, especially in the aspects of applying skills and performance of business units. 
Table 5 Descriptive Statistical Calculations on the Product Dimensions of the New Entrepreneurial Program

\begin{tabular}{|c|c|c|c|}
\hline Aspect & Mean & РКА (\%) & Summary of findings \\
\hline $\begin{array}{l}\text { Increased } \\
\text { knowledge }\end{array}$ & 1.85 & 92.5 & $\begin{array}{l}\text { In general, MSMEs actors participating in the WUB program } \\
\text { have experienced increased knowledge after participating in } \\
\text { the WUB program with data of } 85.09 \% \text { correct answers to the } \\
\text { aspects of MSMEs that were tested. The aspects of knowledge } \\
\text { about entrepreneurial behaviour, business innovation, } \\
\text { entrepreneurial attitudes, and knowledge about business } \\
\text { legality, knowledge about distributors, advanced character, } \\
\text { and characteristics of successful entrepreneurship were the } \\
\text { dominant aspects that were answered correctly by the } \\
\text { participants. }\end{array}$ \\
\hline $\begin{array}{l}\text { Mental } \\
\text { attitude }\end{array}$ & 3.91 & 78.2 & $\begin{array}{l}\text { The mental attitudes of MSMEs participants in the program } \\
\text { tended to change to a positive mental attitude. However, there } \\
\text { are several aspects where MSMEs actors participating in the } \\
\text { program still need to be "upgraded" better, especially in the } \\
\text { aspects of the need for financial records, the need to create } \\
\text { business branding, simple bookkeeping, and digital marketing. }\end{array}$ \\
\hline $\begin{array}{l}\text { Application of } \\
\text { skills }\end{array}$ & 1.88 & 62.7 & $\begin{array}{l}\text { In general, } 50 \% \text { of MSMEs participants in the WUB program } \\
\text { have not implemented company standard workforce } \\
\text { governance. MSMEs do not carry out a recruitment process in } \\
\text { selecting employees. Generally, MSMES employees are } \\
\text { residents who still have neighbouring relationships with the } \\
\text { MSMEs actors. Besides, MSMEs participating in the WUB } \\
\text { program have financial records as well as the training } \\
\text { materials received during the WUB program training. As many } \\
\text { as } 65.3 \% \text { of MSMEs actors participating in the WUB program } \\
\text { stated that they had financial records, and } 46.20 \% \text { had } \\
\text { financial records as recommended. }\end{array}$ \\
\hline $\begin{array}{l}\text { Business Unit } \\
\text { Performance }\end{array}$ & 1.94 & 64.7 & $\begin{array}{l}\text { In general, MSMEs players participating in the WUB program } \\
\text { have experienced significant performance changes with data as } \\
\text { many as } 63.66 \% \text { of the WUB program participants stated that } \\
\text { they have sold their products in attractive packaging, have } \\
\text { carried out business promotions in a controlled manner, have } \\
\text { made production records, have built cooperative networks } \\
\text { partnerships, both with fellow MSMES actors, government and } \\
\text { banking, have sought a hygienic production space, have } \\
\text { written and unwritten business plans, have obtained increased } \\
\text { production and increased income, including an increase in the } \\
\text { number of assets, a wider market reach, have motivation } \\
\text { business, and has an increasing number of partners, especially } \\
\text { among MSMEs actors. }\end{array}$ \\
\hline \multicolumn{2}{|c|}{$\begin{array}{l}\text { Success Rate (PK) } \\
(\%)\end{array}$} & 74.5 & $\begin{array}{l}\text { The process that has been carried out supports the successful } \\
\text { implementation of the New Entrepreneurial Program in Bogor } \\
\text { Regency. }\end{array}$ \\
\hline
\end{tabular}

Based on the results of the percentage of the Total Success Rate of the New Entrepreneurial Program (PKT), it was obtained 79.9\%. Thus, a form of recommendation for the implementation of the New Entrepreneurship program in Bogor Regency in the future, namely the need to improve the quality of the implementation of the New Entrepreneurship program in Bogor Regency so that the goals and objectives of the implementation are achieved optimally. Improvements to the planning and implementation strategy of the WUB program need to be made in the aspects of skill application and business unit performance. 


\section{Conclusion}

In this study, the Determination of Success Factors for the New Entrepreneurial Growth Program in Bogor Regency, West Java has been found. The determination of the success factors of the New Entrepreneurial Program can be done based on the CIPP Model (Context, Input, Process, and Product) which shows the results that in the Context dimension the New Entrepreneurial program is classified as very successful because it is supported by strong legal policies, program objectives that match the needs, and positive program benefits, as well as the right program targets. The Input Dimension also shows that the New Entrepreneurial Program is classified as successful because it is supported by the condition of human resources and conditions of facilities and infrastructure that are following the aims and objectives of implementing the New Entrepreneurial Program in Bogor Regency. The Process shows that several aspects need to be improved, namely the suitability of learning media and the suitability of learning methods, and the Product Dimensions, it is necessary to improve quality, especially in the aspects of applying skills and business unit performance.

In general, the implementation of the New Entrepreneurial Program in Bogor Regency can be declared a success. As part of the effort to accelerate the MSMEs graduation program in Bogor Regency, West Java, the pattern of growing the number and quality of MSMEs can be done by printing "MSMEs Families". "MSMEs Family" is an MSMEs development program that is integrated into one family as one business unit.

\section{Compliance with ethical standards}

\section{Acknowledgments}

The authors greatly acknowledge the support from Jakarta State University, UNJ Indonesia for providing the necessary resources to carry out this research work. The authors are also grateful to the anonymous reviewers and journal editorial board for their many insightful comments, which have significantly improved this article.

\section{Disclosure of conflict of interest}

The authors declared no potential conflicts of interest with respect to the research, authorship, and/or publication of this article.

\section{References}

[1] Dhamayantie E, Fauzan R. Penguatan Karakteristik dan Kompetensi Kewirausahaan untuk meningkatkan kinerja MSMES. Matrik: Jurnal Manajemen, Strategi Bisnis dan Kewirausahaan. 2017.

[2] Indonesia R. Undang-Undang No. 20 Tahun 2008 tentang Usaha Mikro, Kecil, dan Menengah. Jakarta: Sekretariat Negara. 2008.

[3] M Mohd Rosli, Rosman Mahmood. Moderating Effects of Human Resource Management Practices and EntrepreneurPelatihan on Innovation and SmallMedium Firm Performance. Journal of Management and Strategy. 2003; 4(2): $60-69$.

[4] Mulyatiningsih E, Nuryanto A. Metode penelitian terapan bidang pendidikan. 2014.

[5] Nawawi H. Metode Penelitian Bidang Sosial.(cetakan ke-13). Gajah mada University press, Yogyakarta, hal. $2012 ; 176$.

[6] Nugroho SH, Madhakomala R, Gunawan K. The system dynamic model for policy evaluation of navy personnel on the state-duty aspect. International Journal of Scientific and Technology Research. 2019; 8(12): 228-236.

[7] Nugroho SH, Madhakomala R, Gunawan K. Analysis and scenario of navy performance allowance policy using system dynamic model. International Journal of Scientific and Technology Research. 2019; 8(12): 1140-1147.

[8] Nugroho SH, Sukandari B, Suharyo OS, Bandono A. The application of Nasa-Tlx methods to the analysis of Mtf navy personnel allocation. International Journal of Scientific and Technology Research. 2020; 9(3): 6172-6179.

[9] Nugroho SH, Sukandari B, Bandono A, Sri Suharyo O. The applications of model bayesian networks for analysis and preventive actions on maritime security operations. International Journal of Scientific and Technology Research. 2020; 9(3): 3000-3006.

[10] Reeg C. Micro, small and medium enterprise upgrading in India: learning from success cases (No. 78). Studies. 2013. 
[11] Singarimbun M, Effendi S. Metode Penelitian Survei, Jakarta. Kegiatan Wisata Bahari di Resort Pengelolaan Wilayah Pulau Harapan Taman Nasional Kepulauan Seribu. 1989.

[12] Suharjo B, Suharyo OS, Bandono A. Failure mode effect and criticality analysis (FMECA) for determination time interval replacement of critical components in warships radar. Journal of Theoretical and Applied Information Technology. 2019; 97(10): 2861-2870.

[13] Suharjo B. Using System Dynamics to Analyze the Leadership Style on Motivation and Soldier's Performance. In E3S Web of Conferences (Vol. 125). EDP Sciences. 2019.

[14] Susilo AK, Putra IN, Ahmadi, Suharyo OS. Analysis of national maritime security strategy as an effect of regional development using SWOT, fuzzy multi-criteria decision making (FMCDM), and borda. International Journal of Operations and Quantitative Management. 2020; 25(3): 153-174.

[15] Suharyo OS, Djauhar Manfaat, Haryo D Armono. Establishing the Location of Naval Base Using Fuzzy MCDM and Covering Technique Methods: A Case Study, International Journal of Operations and Quantitative Management, IJOQM. 2017; 23(1): 61-87.

[16] Statistik BP. Jumlah Usaha Mikro Kecil Tahun 2010-2014 di Indonesia. Jakarta (ID). 2015.

[17] Warcito W, Ikhwan K, Butarbutar PH. Pemetaan Pelaku Usaha Mikro Dan Kecil Di Kecamatan Cicurug Kabupaten Sukabumi. Jurnal Manajemen (Edisi Elektronik). 2020; 11(1): 60-70.

[18] Warcito W, Akbar M, Hamidah H. Performance Human Resources of Owners Micro and Small Businesses In The Upgrading MSMEs Program, Bogor District. Jurnal Manajemen (Edisi Elektronik). 2020; 11(2): 139-151.

[19] Yu MC. The Influence of High-Performance Human Resource Practices on Entrepreneurial Performance: The Perspective Of Entrepreneurial Theory. International Journal of Organizational Innovation. 2013; 6(1).

[20] Zimmerer TW, Scarborough NM, Wilson D. Kewirausahaan dan manajemen usaha kecil. Jakarta: Salemba Empat. 2008; 85. 